Journal of Educational Method and Technology Vol. 2 No. 2, Agustus 2019

P-ISSN 2622-8459 E-ISSN 2622-8467

http://ejournal.unima.ac.id/index.php/jemtec

\title{
The Utilization Of Sawdust Waste As A Media For Sculpture
}

\author{
R Rantung ${ }^{1}$ \\ ${ }^{1,2}$ Universitas Negeri Manado, Indonesia \\ corresponding author: ${ }^{1}$ rulyrantung@unima.ac.id
}

\begin{abstract}
Technology has penetrated into the community as a necessity for the sake of acceleration, while art is an inseparable part of the needs of every human being's life, both fine art and applied art. Technology and art cannot be separated at every step forward but the residual waste of technology can used into works of art without using technological aids. Some sculpture works made of wood, cement, fiberglass, metal (brass). This research will look at the extent to which sawdust can used as a medium for making sculptures. Sawdust waste is found in many furniture industries and stage home industries. With sawdust for creative people can used as material for art work.
\end{abstract}

Keywords: Sawdust; Waste; Sculpture

\section{Introduction}

Art and technology are two human works that always coexist in the development movement in this modern era. Technology penetrated into the community as a necessity for the sake of acceleration, while the work of art is an inseparable part of the needs of the technology itself even in the necessities of life for every human being. Both fine art and applied art these two types of works are inseparable from human dignity of life. There are works of art that can only be enjoyed by certain people because the sale price of a work is not affordable by people from the lower middle class economy. But there are many popular works of art such as souvenirs, sold freely made from various types of raw materials. Souvenir types of art that are often called "craft arts" will done by not choosing the time, anytime and anywhere, according to the type or motive that be created, even it will be one of a source of family income through home industry. It said that art is one of the human needs that they can be proud of, especially if the work wants to live and develop with new creations without leaving the characteristics of the nation and the region and be able to touch life in the era of new technology. To create a work of art does not have to need large funds but requires creativity. How to use waste so it can be processed into works of art? On this occasion sawdust which is nothing but the waste of the furniture industry and the stage home industry will used as a medium for making sculptures.

\section{Specific Research Objectives}

This study aims to bring up something new based on facts in the field by utilizing sawdust waste as a natural resource in the Woloan - Tomohon stage house industry. 
Journal of Educational Method and Technology Vol. 2 No. 2, Agustus 2019

P-ISSN 2622-8459 E-ISSN 2622-8467

http://ejournal.unima.ac.id/index.php/jemtec

\section{Benefits of Research}

- To offer clear information about the benefits of sawdust waste after being processed into a medium for making sculptures.

- Train participants to learn or even people who want to work creative by using media work.

\section{Research Urgency}

The classic issue that is often the reason for art workers to not work is the high cost of the creation process, especially sculpture. As cement purchased, wood media requires equipment that must be purchased, moreover fiberglass in addition to the expensive price, the manufacturing process should professional. Sawdust wasted on piles around the stilt house industry and the furniture industry, but the extent to art workers creativity by using it to be used as a medium for processing of sculptures.

\section{Targeted findings:}

- A set of sculpture works made from sawdust media.

- Sawdust can be used as a medium for artistic work

\section{Literature Review}

\section{Sawdust}

In general, companies that produce powdered wood (furniture) equipment have produced during this work. Sawdust or wood powder is a waste of the sawmill industry. One of the issues in question so far is wood sawdust and many problems in handling it are often left to rot by entrepreneurs / craftsmen, stacked and burned all of which have a negative impact on the environment so that the countermeasures need to considered, as shown below:
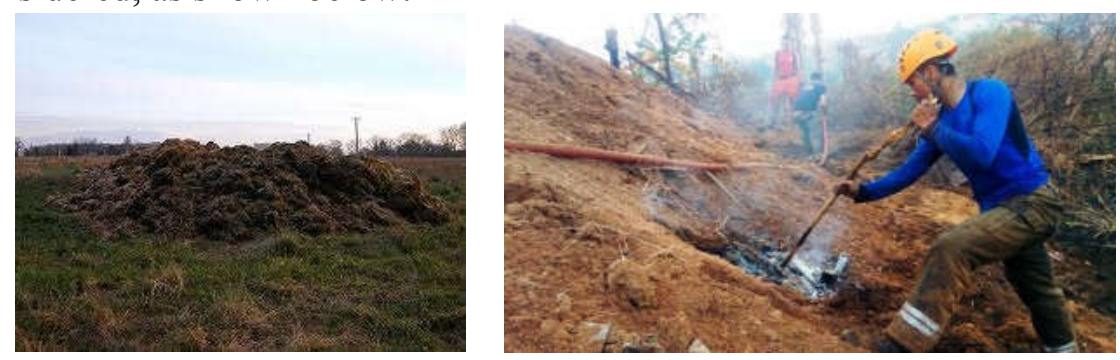

If it assessed the impact of powder waste can actually endanger the human environment, but with current technological advances sawdust can used as one of the ingredients in the manufacture of concrete blocks. The results of the study said that the sawdust mixture in the brick making can reduce production costs, and it said that the brick making's quality is also not as good as the type of brick making which does not use a mixture of sawdust. In addition to making waste bricks, it can also be processed for certain needs such as

1. As fuel

2. As base to keep hamsters

3. Growing media

4. Sawdust briquettes

The benefits of wood sawdust can be processed into briquettes. This briquette can be used as a substitute for firewood and kerosene in daily necessities. Briquettes 
Journal of Educational Method and Technology Vol. 2 No. 2, Agustus 2019

P-ISSN 2622-8459 E-ISSN 2622-8467

http://ejournal.unima.ac.id/index.php/jemtec

made from wood saws waste have a lower price than coal briquettes. When compared with the use of natural gas and kerosene, briquettes from sawdust are much more effective and can certainly reduce household expenditure.

\section{Processing and making paper}

One of the basic ingredients of paper making is wood powder. In addition to the commonly used white paper, sawdust waste is also used to be processed as recycled paper, which is usually brown in color and has a rough texture. This recycled paper is often used for activities or uses that are aesthetic and related to arts and crafts. The sawdust in its use becomes a value-added product with applicable and populist technology so that the results are easily socialized to the community, including processing waste powder into works of art.

\section{Sculpture Art}

Sculpture is one of the sciences that must learned and know how to make it and how it processed. A statue is an object that has a weight in the form of three dimensions of a human work whose existence is specifically recognized as a work of art. The purpose of creating sculptures is not to worship or be worshiped but to produce works of art that can enjoyed by many people and can last as long as possible. Therefore the statue made by using materials that are durable and expensive. Expensive statues are often made of materials such as bronze (metal), marble, granite, and some are even made of ivory, gold and silver. Materials that are commonly used in making sculptures and are not very expensive include wood, clay, metal. In making the statue in the present is different from the past, in the past the statue created and made as an idol, symbol of God or a deity worshiped. Along with the advancement in the way humans think the statue is no longer an idol but it was created into a work of art that can be enjoyed or called pure works of art. Indeed there is such a thing as a religious statue, the purpose of making this statue is to use to worship and religious significance for some religious communities. Understanding sculpture is a work of art in three-dimensional form, meaning that the work has volume or content. Sculpture can also be called a work of plastic art (palastic art), so the meaning of plastic, it can formed as desired. Sculpture is also known as a form of art that has the value of beauty in the results of the work. Sculpture as an art form actually has a broad meaning, because the results of the work are not only in the form of humans and animals, but can also be in any form as long as the three dimensions have volume and contain elements of beauty. One technique that is often used in making sculptures is carving. The tradition in making sculptures originally came from western countries, namely since ancient Greece, when the statue has seen as a form of great art.

If the sculpture seen from its function, the following are generally the functions of the statue based on the purpose of its manufacture, including:

Religious Sculpture, a sculpture that has religious elements and meanings, is usually used to worshiping certain beliefs.

- The Monument Sculpture, made with the aim to commemorate historical events or to commemorate the services of a person / group.

- Architectural sculpture, made to support the architecture or construction of a building so that it is also valuable for aesthetics or beauty. 
Journal of Educational Method and Technology Vol. 2 No. 2, Agustus 2019

P-ISSN 2622-8459 E-ISSN 2622-8467

http://ejournal.unima.ac.id/index.php/jemtec

- Handicraft Sculpture, made to decorate a building or beautify the environment. Craft sculpture, a sculpture made from handicraft works, the results are be enjoyed by its beauty.

- Art sculpture, made only be enjoyed its beauty

\section{Media and Sculpture Making Technique}

Sculpture art material

\section{Soft Materials}

That is the material for making sculptures that have a soft texture so it is easy to shape. For examples: clay, clay, plasticine, soap, etc.

2. Medium ingredients

That is the material for making sculptures whose textures are not too hard like wood, such as: mahogany, wood, wood, etc.

\section{Hard material}

That is the material for making statues that are hard and complicated, generally made of stone, but there are also certain types of wood. For Examples: granite, marble, andesite, teak, rosewood, etc.

\section{Some of the tools used in making sculpture}

1. Butsir

It is a tool that is useful to reduce or add material to make the statue so it becomes the desired shape. Grains are generally used to make sculptures from free material.

2. Turntable

Namely a table that can be rotated to make a statue, its function is to control and make it easier when it making from all directions. Usually be used to make clay sculptures.

3. Chisel

It is a tool used for sculpting and carving, this tool is useful for reducing materials. There are generally two types of tools, for carving wood and for carving stone or a tool for carving, supported by providing driving force on the chisel so that the basic material of the sculpture can adjusted as desired.

4. Mold

It is a tool used to make sculpture works made from liquid material.

5. Parrot

It is a tool made of iron, shaped like a parrot's beak. Its function is to tighten the bonds of wire and to push the wire.

6. Spoon the dough

This is the tool used to take the dough and stick it to the saved statue.

\section{Technique of making sculpture}

1. Butsir

It is a technique that uses massaging, adding, and subtracting material to make a sculpture, completed with a tool called Grain. The material used is usually soft and easy to shape. Such as clay, plasticine, etc.

2. Sculpt

It is technique in making sculpture by reducing materials. In addition to using the Chisel tool is usually equipped with other tools that support in making sculptures 
such as hammers, saws, etc. Materials used are hard textures such as granite, marble, andesite, teak, etc.

3. Cast technique

It is a technique that generally uses cement and sand, after it has thawed then poured into a mold and allowed to harden. In addition to using cement and sand, you can also use iron, bronze, silver, etc. that has melted and then poured into a special mold.

\section{Aesthetics}

Specifically about a sense of beauty, people can only know what it is if they have never experienced it because it was not heard or told. Clive Bell formulates its aesthetics as follows; beauty can only be found by people who in themselves have experience that can recognize meaningful forms in a particular object or work of art with vibrations or stimuli of beauty (Sutrisno \& Verhaak, 1994). Aesthetic experience related to the concept of illusion which is specifically expressed by E.E. Gombich in his book "Art and Illusion" (1960). In his opinion, art is an illusion because on the one hand no specific model to emulate. On the other hand, if there is (another model that can be replicated) the imitation cannot be used as a standard of objectivity.

By understanding Gombich's definition above, the question arises: what is the real work of art. Because it is in the understanding of the philosophy of beauty then the answer will directed at the aspect of logical realism, the aspect of phenomenalism, idealism. Sachri (1992) writes that the adherent of idealism says that the artwork is basically not physical in nature, because it is a product of mental and spiritual activity or imagination (creative). The process of birth of art is more a process of forming ideas and not demonstration or materialization into art objects. In terms of phenomenalism, it explains that the artwork is not physical, but refuses to see it as universal. Artwork is both a perceptual and aesthetic object at the same time, even though the perceptual object is not an actual part of the work of art. For a phenomenal person, it is difficult to deny that works of art are physical, but works of art should have paired with aesthetic objects.

Departing from some of the statements above, with views and opinions, which by the public consider that view is only a theory of consumption of scientists, apart from that all works of art must have seen as something inseparable from humans, art is the deepest expression of taste in humans, he is also free to decide how it will manifest. Meanwhile, if that art comes and alighted on an artist who is steadfast with his idealism, then he tends to become a work of art which is considered pure.

\section{Purpose And Benefits Of Research Specific Research Objectives}

1. With ability of creativity whether sawdust can use as a medium for sculpture.

2. To state the facts about the use of sawdust, it can be used as a medium for sculpture. 


\section{Benefits of Research}

1. As a media for learning to be creative for children, even parents to make use of waste into works of artistic value.

2. To protect the environment by turning waste a useful works for the economy.

\section{The Method of Creation}

\section{A. Creation Process}

This research is generally oriented towards the creation process, with the following framework:

a. Pre ideas

b. Idea

c. Contemplation / contemplation

d. Motivation / stimulation

e. Design / planning

f. Artwork

The steps in data collection are:

1. Literature study

2. Location Study

3. Study documentation

4. The website

B. Plan of activities as follows:

Preparation:

- Location survey, library study

- Prepare documentation instruments, digital photo cameras,

- Prepare work equipment.

- Arranged travel itineraries.

Field work:

- Sampling on several types of sawdust

- Collecting sawdust

- Make a sculpture design

- Processing sawdust waste Make / do

The main indicators as a measure of sawdust analysis are:

1. The type of sawdust that has been finely identified.

2. The type of sawdust was identified from processed wood that is not easily eaten by termites.

Target indicators in this study include:

1. The resulting type of fauna statue.

2. Can be exhibited as a result of sculpture.

\section{Stages of research implementation:}

1. Pre Field

a. Determination of place / sampling area for powder.

b. Determination of sampling time to the location

c. Sampling location survey

d. Researcher's preparation 
Journal of Educational Method and Technology Vol. 2 No. 2, Agustus 2019

P-ISSN 2622-8459 E-ISSN 2622-8467

http://ejournal.unima.ac.id/index.php/jemtec

Indicator:

a. The time can determined in carrying out activities that located in Woloan District, Kec. Tomohon

b. The research instruments availability and transportation facilities that will used by researchers.

1. Field Activity:

a. Search for types of sawdust.

b. Sampling of types of sawdust

c. Identify the types of sawdust that can be used

d. Processing sawdust.

e. Formation of the work according to design

f. Finishing

Indicator:

a. There are sawdust that can used to make sculptures

b. Can be easily processed for the sculpture making process.

c. Generate beautiful sculpture geniuses

Research procedures (items 1 and 2) will carried out in 2019, conducting research from the field up to the analysis and compilation of reports predicted to offer a new record as a useful creation for the creative process of art creation.

\section{Workmanship Process}

1. Make a Design

The important thing that cannot be underestimated in the work process is to make a design or work plan. What form will be created then depends on what kind of design was made.

2. Prepare ingredients.

The material needed in the process of work is wood sawdust which has been well selecting because there are types of sawdust which are rough and some are smooth. The powder used has filtered first.

3. Preparation of work equipment

Many types of tools will used in this creation process. But a number of work tools for making sculptures have shown in Chapter II so there is no need to display them again in this section.

\section{4. $\quad$ Research Results And Discussion}

Research result

This research focused on the use of wood sawdust as a media for creating art, with the work process as below:

\section{Steps of work}

- Prepare a $6 \mathrm{~mm}$ wire with a length of $200 \mathrm{~cm}$. This wire is for the purpose of supporting the statue as well as function of two bird legs that will plugged into a piece of board to place a bird's stand. Make a sketch of a bird that want be made.

- Prepare a wire has a size of $40 \times 40 \mathrm{~cm}$ to wrap the wire that serves as a place to stick sawdust. Make a sketch of a sculpture accordance with Figure 10. 


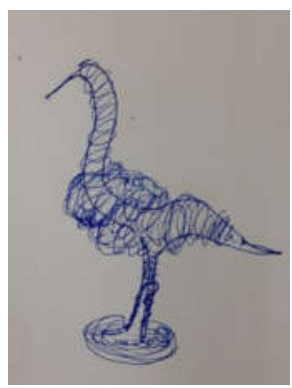

- Fox glue $1.5 \mathrm{~kg}$.

- Prepare a fine sawdust to taste, then mixed with glue (Fox glue), stirring until evenly distributed, then gently placed on the bird's skeleton that has made until the skeleton closed. Shape the anatomy of the bird according to the design. Let stand until it dries naturally and then after it dried, tidy it with sandpaper.

To make a bird's natural then finish the last stage by using paint.

\section{Discussion}

Sawdust from furniture craftsmen is an ongoing problem. Piles of sawdust that decomposes even the pile of burned powder is equally problematic. Countermeasures that are often done are by burning so as not to add a bigger pile. The use of powders for plants does not mean spending pollen in piles but in essence only reduces volume. Likewise, it is the same if used to make briquettes.

The use of powder as a medium for making art works does not make sawdust processed by the furniture company used up, but when compared to just burning and letting it rot, the use of a little but can give added value will be more meaningful than others. Artwork whose settlement is worth selling will add to the family's economy and had the opportunity to create its own employment with the term creative industries.
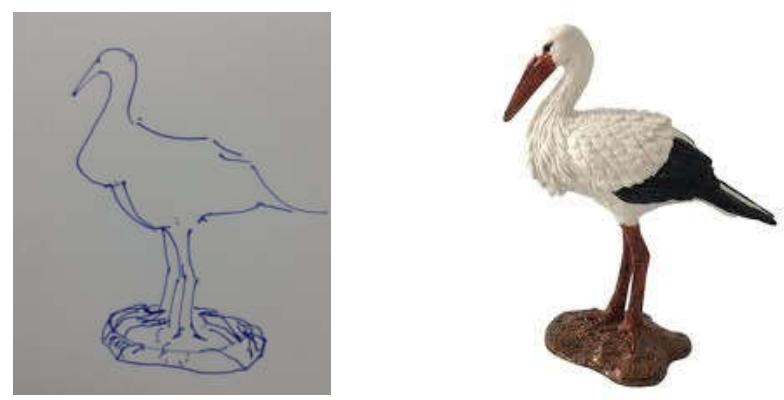

\section{CONCLUSIONS AND SUGGESTIONS \\ Conclusion}

The final results in this study in its completion show that sawdust / sawdust can used as a medium for making sculptures, with sounds that resemble kolintang from wood. With work processes that match the rarities and supported with materials needed, the work process is finally satisfying. The making of sculptures made from sawdust / sawdust does not cost much because the main material is from 
woodworker's waste. On the process of selecting sawdust in media researchers. Even though wood craftsmen use various types of wood in their work, because until when the researchers wrote the results of this study, it was not obtained what kind of wood the powder could last a long time and was not eaten by moths.

After going through the process it can concluded that sawdust can used as a medium of artistic work, especially to make types of sculpture that are still of modest size. If the framework of the construction statue is bigger and stronger to bear the burden, then sawdust can also be made of a larger sculpture.

\section{Suggestion}

Creation requires creativity in utilizing materials that are around the environment. The works creation of art does not merely have to cost a large amount but the extent to which a person's ability to use material that is possible for many people considered useless.

It turns out that wood sawdust can created into a sculpture, so it is recommended for art lovers be able to be creative with any media which is considered by many people to be worthless and valuable. Thus works creation of art does not mean having to spend a lot of money because they buy materials and media that are expensive but can use the materials that are around the environment.

Research Output

a. Sculpture works made from sawdust.

b. The new notes from the results of this study will give an understanding of the current generation as a critical study of regional cultural values that inherited to be preserved by the natural resources that exist around the environment.

\section{REFERENCES}

Dharsono Sony Kartika, 2007,.Estetika, Rekayasa Sains, Bandung.

Eckholm, Erick P., 1984. Krisi Energi Kayu Sumber Daya Pembaharu, Yayasan Obor Indonesia, Jakarta.

Graafland, N., 1991. Minahasa, Negeri, Rakyat dan Budayanya. Terjemahan; Lucy R. Montolalu.Jakarta : Pustaka Utama Grafity.

Gustami, SP, 1980. Nukilan Seni Ornamen Indonesia. Sekolah Tinggi Seni Rupa Indonesia, Yokyakarta

Haryadi dan B. Setiawan., 1996. Arsitektur Lingkungan dan Prilaku.Suatu Pengantar ke Teori, Metodologi dan Prilaku.Jakarta, Lembaga Pembinaan dan Pengabdian pada Masyarakat.

Kalangi, N. S., 1995. Kebudayaan Minahasa, dalam Kuntjaraningrat., ed. Manusia dan Kebudayaan Indonesia.Jakarta : Djambatan.

Kartodirdjo, Sartono, 1987. Kebudayaan pembangunan dalam perspektif sejarah. Gadja Mada University Press, Yokyakarta

Kerlinger, Fred N., 2003. Azas-Azas Penelitian Behavioral, Gadja Mada University Press, Yokyakarta.

Kaunang, AK., et all, 2005. Prempuan Minahasa dalam Arus Globalisasi, Meridian, Jakarta.

Kaunang, Ivan R.B., et all. 2005. Sejarah Kabupaten Minahasa Utara (suatu perjuangan dan tidak mengenal lelah). Manado : Pustaka Jender BKOW Sulut. 
Journal of Educational Method and Technology Vol. 2 No. 2, Agustus 2019

P-ISSN 2622-8459 E-ISSN 2622-8467

http://ejournal.unima.ac.id/index.php/jemtec

Koentjaraningrat, 1984. Kebudayaan Mentalitas dan Pembangunan, PT Gramedia, Jakarta.

Kotambunan, R. E. H.., 1985. Minahasa II dan III.Pemerintah Purba sampai kedatangan V.O.V dan Tiga Perang Tondano. Manado: PT Cipta Buana.

Lauer, Robert H., 1989. Perspektif tentang Perubahan Sosial. Terj. Alimandan, Jakarta; Bina Aksara.

Marianto, M. Dwi, 2017. Art \& Life Force in a Quantum Perspective, Srisasanti Syndicate Institut Seni Indonesia Yokyakarta.

Sendoh, Joutje., 1997. Sejarah Perkembangan Masyarakat Minahasa dan Perjuangannya, dalam J. Turang et al., Profil Kebudayaan Minahasa.Tomohon : Majelis Kebudayaan Minahasa.

Soedarsono, RM., 1985. Peranan Sejarah Dalam Kehidupan Manusia: Kontinuitas Perubahannya, Universitas Gadja Mada, Yokyakarta.

The Liang Gie, 2000,. Garis Besar Estetik (Filsafat Keindahan), karya, Yogyakarta.

Thomas Munro. 1969,.The Art and Their Interreletions. Clevaland and London: The Press of Case Western Reserve University, p. 473. 88 Ambar Astuti, op., cit.,p. 39.

Umar, Kayam, Kreativitas Dalam Seni dan Masyarakat Suatu Dimensi Proses Pembentukan Budaya dalam Masyarakat, dalam Analisis Kebudayaan, Departemen Pendidikan dan Kebudayaan, Jakarta. 1981/1982 